\title{
Words and Meanings of Love in Arabic and English with Reference to Translation
}

\author{
${ }^{1}$ Marwan Muhammad Hussein, 2Safwan Idrees Thannoon \\ ${ }^{1,2}$ Department of Translation, College of Arts, University of Mosul, Mosul, Iraq
}

\begin{abstract}
The research is an attempt to shed light on words of love in both Arabic and English for the sake of showing the main differences and similarities between both languages and ways of thinking by the speakers of both cultures.

Each word carries a positive and/or negative sense which may be covered by the so-called word nuances. Arabic words are unique in their denotation with different connotations. Therefore, it is difficult to say that a word can stand for another one because Arabic words of love, as the study reveals, are to varying degrees highly emotional and meaningful. English words of love, on the other hand, are clear and forward, frequently associated with sex in modern English. For this reason, they are elaborated on separately as a threshold to discuss the main problems emerging in translating some of them particularly, from Arabic into English. It is found that there is no one-to-one correspondence, except for few of them, between the Arabic words and their English counterparts.

The research indicates that the translation of words of love is highly stylistically and contextually bound. Hence, translating such words requires a well-versed and competent translator.

Finally, the research comes up with some conclusions that have been arrived at during this work.

Keywords: Words, Means, Translation.
\end{abstract}

\section{Introduction}

One of the major themes in literature is love; in fact, love and death are the essence of literature. And to show this noble human feeling, we find love has many words and meanings in both Arabic and English, which express various types of agonies, sufferings, tortures, happiness and joy. However, the words and meanings of love in Arabic are more in number than in English. As a matter of fact, there are about sixty words that express love in Arabic (Qutub,1991:12). The research deals with the most common Arabic words, while at the same time, discusses and demonstrates the few numbers of words expressing love in English. Thus, it is a comparative study that sheds light on the differences

Academic Journal of Nawroz University

(AJNU) Volume 8, No 4 (2019).

Regular research paper : Published 26 Dec 2019

Corresponding author's e-mail : mashallal44@gmail.com Copyright (C2018 Marwan Muhammad Hussein, 2Safwan Idrees Thannoon. This is an open access article distributed under the Creative Commons Attribution License. and similarities of both concepts - Arabic and English and how they look at love, and the beautiful images love words give in describing human feelings. More importantly, the research discusses the problems raised in translating some Arabic words which have no equivalents in English and what alternatives one has in facing such situations.

Love is an emotion of strong affection and personal attachment. In philosophical context, love is a virtue representing all of human kindness, compassion, and affection. It refers to a variety of different feelings, states, and attitudes, ranging from pleasure (I loved that meal) to interpersonal attraction (I loved my partner). Love may refer specifically to the passionate desire and intimacy of romantic love to the emotional closeness of familial love, or the platonic love, that defines friendship, to the profound oneness or devotion of religious love (En.wikipedia.org / wiki / love: 2017). The hypothesis put forward in this study is that the 
translator of these Arabic words, namely, love words fall short at finding their equivalents in English. As for the problem investigated in this study, it is related to the following questions that the study attempts to answer of which the following:

- What is the best solution for that case when there is no one-to-one correspondence between English and Arabic?

- What is the main problem in the use of words of love as far as translation is concerned?

\section{Words of love in English}

The word 'love' has few synonyms. In this research, common words of love have been chosen; those used on a large scale such as (adoration, affection, infatuation, passion, longing, enchantment, yearning, attachment, fondness, and devotion) (Fallows,1988:163).

Each one of these words has its meaning taken from the English dictionary.

Adoration: to love deeply, to live it very much, to worship as divine.

Example: His adoration for Jane is beyond limits.

I love her, I adore her, she is my life.

Affection: love, liking.

Example: The deep affection he has for his beloved made him forget all her faults.

infatuation: To inspire with a temporary intensive unreasoning love for a person or thing.

Examples: Romeo's infatuation with Juliet paved the way for his downfall.

His infatuation with her beauty turned him upside down.

Passion: strong emotion, sexual love .

Examples: He is filled with passion for Amanda.

He is too much worried, he cannot control his passion .

Longing: intense persistent wish.

Examples: She longed for him to say something.
The children are longing for the holiday.

A longing for home.

Enchantment: to put under a magic spell, to delight very much .

Examples: she was enchanted with the flavour you sent.

Her enchantment on young minds is great.

Jack's personality has a strong enchantment on old women.

Yearning: long for with tender feeling, affection .

Examples: He yearned for a sight of the old, familiar face.

His yearning is always to return to his native land.

Attachment: be bound to by love or affection.

Examples: She is deeply attached to her young brother.

He is foolishly attached to old customs.

Fondness: be full of love for, take pleasure in .

Examples: A young wife with a fond husband.

He is fond of music.

Devotion: deep, strong love .

Examples: The devotion of a mother to her children.

He is too much devoted to his duty.

(Hornby, 2010 ; Ehrlich et al.,1980 )

Finally, we have to mention the modern meaning of the word 'love'. And here we find it is related with sex. It is used on a very large scale - in the English society ordinary daily talk, in their songs, they express it freely and without hesitation. The following song by Janie Fricke helps in judging this point:

Don't worry about me, baby

I'll be alright

Don't worry about me, baby

Just love me tonight

The impression one gets from these popular songs is undoubtedly to have sex and nothing else. However, it is important to mention here that the synonyms of 
'love' we have demonstrated earlier are, though they seem simple, clear and forward; they do not usually have metaphorical images, whereas in Arabic, as we are going to see, the words of love are highly metaphorical; they stimulate a lot of interesting meanings and poetic images.

\section{Words of Love in Arabic}

The word 'love' as a noun is stated in the Glorious Quran more than eighty times(Qutub,1991:7). They are various in derivation and structure; most of them concentrate mostly on the noble relation, emphasize generality, and exceed the physical relationship between man and woman. Since Arabs had different concepts concerning the meaning of love, they had many different names depending on the variety of their feelings and emotions that come to their minds. As a matter of fact, the words of love in Arabic are about sixty words. Here are the most common important ones (Ibid:12):

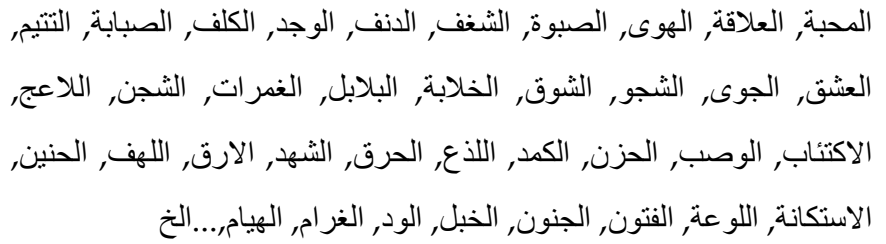

Generally speaking, when one analyzes these words, s/he finds that they present emotional and mental states conveyed in interesting and beautiful poetic images, describing the relationship between man and woman. However, the research will tackle only the most common ones:

المحبة: It comes from purity, The Arabs used it to describe the whiteness and freshness of teeth. حباب It is said that it comes from the word which means the thing that floats on water (www.almaany.com). حباب is the plural form of حب (Ibid). The image here is like the burning of the heart when it longs to see the beloved. The Arabs say: The camel kneels down and does not rise up. Likewise, the lover is committed to his beloved's heart.

الهوى: It means the inclination of the heart. It is used sometimes in a negative sense. Allah the Almighty says in the Holy Quran:

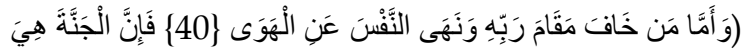

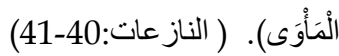

And sometimes, it may be used in a positive sense but with reservation, like the discourse of the prophet, (may peace be upon him), لا يؤمن None of you truly believes until his inclination is in accordance with what I have brought" (https:// sunnah.com).

الصبوة: It means the tendency towards ignorance and misbehavior. Prophet Joseph, may peace be upon him, says in the Holy Quran: وَإِاًَ تَصنْرِنْ

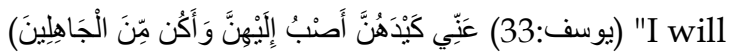
feel inclined towards them and be one (of those who commit sin and deserve blame or those who do deeds) of the ignorant" (Khan and Al Hilali,2007:318).

It is noteworthy to mention that الصبوة is not like الصبابة which means the intensity of love.

الثغف: It is taken from الثغاف which means 'membrane of the heart'. Allah the Almighty describes in his Holy Quran the woman who tried to seduce prophet Joseph, may peace be upon him

"indeed she loves him violently" (Khan and AlHilali, 2007:317)

: It is the love that causes sadness and melancholy. It is very common in the Elizabethan poetry. For example, Romeo's love for Rosaline.

الكلف: It is the intensity of attachment. It is taken from the word مشقة, which means hardship. Allah

This Prophetic hadith is related with weak chain of narrator ${ }^{2}$ 


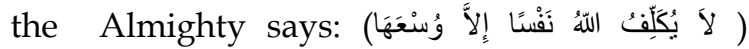
(البقرة:286) "Allah burdens not a person beyond his scope" (Ibid:78).

العشق : It is the extremity of love, and it is so called because it is stuck to human heart.

الجوى: Anguish which combines both the extremity in love and melancholy.

الثوق : It is the travel of the heart to the beloved, the travel of his emotions and feelings. Prophet Muhammad, may peace be upon him, says in و أسالك لذة النظر الى وجكلك, و الثوق ( one of his prayers I I ask you for the sweetness of looking upon your Face and a longing to encounter You.. " (forums.way2Allah.com).

الوصب: It is the pain, the agony of love and its suffering, because the cause of وصب is hardship. Prophet Muhammad says :

لا يصيب المؤمن من هم ولا وصب حتى الثوكة يثاكها الا كفر الله بها من ) No trouble comes to a believer even if it is the pricking of a thorn that it becomes whereby his sins are effaced" .

And sometimes, this word وصب has the meaning of constancy, like the following verse: (َلَهُمْ عَذَابَ "and theirs is a constant (or painful) torment".

الاستكانة: It means submission and surrender. Allah the Almighty says :

but they humbled not themselves to their Lord, nor did they invoke (Allah) with submission to Him" (Khan and Al Hilali,2007:465)

الود : The pure, tender love, accompanied by pity and mercy.

:الظلة: companionship. It is called so because it is interrelated with human soul (Qutub,1991:19). It is a degree which does not accept sharing المشاركة. That is why Allah the Almighty chose only two companions خليل the first one is

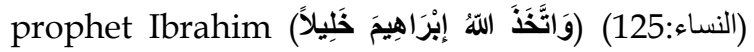
"And Allah did take Ibrahim(Abraham) as a Khalil (an intimate friend)" (Ibid:142), and the second is Prophet Muhammad ( ان الله اتخني خليلا (كما اتخذ ابر اهيم خليلا).

الغرام: It is something related with debt to pay or the price one must pay. Allah Almighty talks about

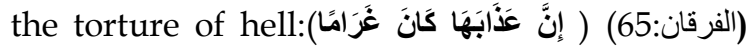
"Verily, its torment is ever an inseparable, permanent punishment" (Khan and $\mathrm{Al}$ Hilali,2007:489)

الهيام: It is the madness of love. It comes from a malady that affects camels which makes them go astray, or it means the thirsty camels. Therefore, the image here is that the lover in a certain condition...he is so thirsty to see his beloved. $\mathrm{He}$ is mentally and psychologically broken down- almost an insane person.

التعبد: Worship. Here, we reach the highest point of love...adoration. Adoration is the aim of love. This kind of love is considered as the most honoured one. And it is only qualified and suitable to Allah Almighty, because it is His right upon His people. (Qutub,1991:13-21).

\section{The Translation of words of Love}

From surveying the words and meanings of love in Arabic, it is found that most of them present images - poetic images that tell something about the person. Further, they give a chance to make interesting comparisons like the word المحبة which compares the burning heart with the thing that float over the surface of water during heavy rain. Likewise, the comparison between kneeling down of the camel and the lover kneeling to his beloved. The camel kneels down and does not rise up, and the lover also kneels down (submit) and cannot forget or abandon the beloved. In 
addition, the word المحبة is related with the whiteness and tidiness of teeth. The Arabs say حباب الاسنانwhich means the tidy teeth(www.almaany.com).

Now the point is that... what is the equivalent in English? How can we translate all these meanings and feelings?

The English words that express love, as we have seen earlier, are simple, clear and forward. It is a problem, a real problem that needs a solution.

Another case for discussion is the word هوى which has two meanings. The first one means 'air', while the second one means 'love'. If we say in English the following sentence:

You fell down or the air made you fall down?

For the Arabic sentence (انت وقعت والا الهوى رماك))

Does it come to any English-speaking person's mind that the sentence is about love? Of course not.

It is another problem which needs solution and reconsideration. Sometimes, the use of 'air' for هوى in English will sound not only funny but ridiculous. Consider the following song:

The air is mine

For the Arabic song... (الهوى هواي)

The same thing could be said about the rest of the Arabic words that stand for love, whereby we find difficult equivalents in English that express and carry the same meaning. All what is found in English in solving such problems is the addition of words to the word 'love'; for example, they say in English: He loves Jane deeply, profoundly or madly.

And sometimes, they use some words and expressions like:

He is crazy about her, or

He is from top to toe in love with her

To express the type of love he has for her, unlike the Arabic words where each word can give the whole meaning independently.
Seemingly, the words of love, mentioned above are numerous. In spite of their similar meanings, they are different in their connotations. It means "the cluster of implications that words or phrases may carry with them, as distinguished from their denotative meanings" (Holman,1980:98). Synonymy is known as sameness of meaning. However, it is often argued that no two words with exactly the same meaning would both survive in a language (see Palmer, 1981:91-93). If so, we have to expect a wider gap between the meanings of different languages due to the different cultures, histories, beliefs, etc. The following lines taken from Arabic are a good example to prove this point:

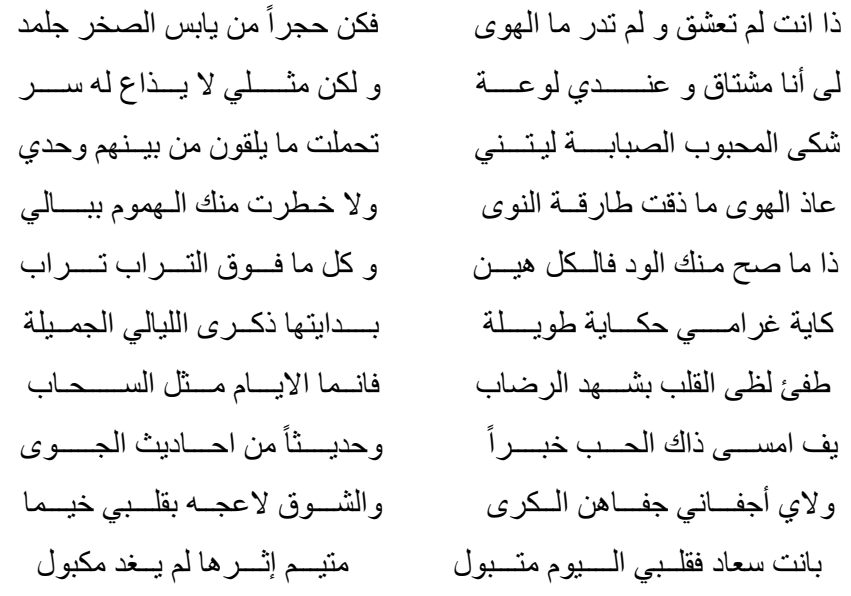

In this respect, the translator has to find suitable equivalents to the above underlined words. According to Catford, textual equivalent is " any TL form (text or portion of text) which is observed to be the equivalent of a given SL form" (Catford,1965 :27). However, the problem here is that to what extent can a translator succeed in conveying as much as possible the spirit and sense of the original words of love, especially from Arabic into English?

For this purpose, five teachers in the Department of Translation / College of Arts / University of Mosul with different academic status have been chosen as subjects in this research. However, the research is not concerned with the translation of poetry; rather it is concerned only with translating the words of love 
themselves like الهوى, الود, غرامي, تعشق, الجو, etc. And here we face the difficulty of translating such words into English because, perhaps, 'love' is the first thing that comes to the mind when facing Arabic words. Second and more important, there is no agreement among all the renderings of a specific word of love.

In the first line, for example, the word تعثق is translated into( love, passionate, adore, fall in love), and the word الهوى is translated into (love, affection, fancy, and passion). This shows, undoubtedly, that the Arabic words are not only difficult to translate but also constitute a burden for translators especially in differentiating the images -the poetic images- even among Arab readers themselves. Therefore, it is not easy to say that a word like 'love' can always stand for the Arabic word هوى. In the Holy Quran, the word هوى an an entirely different meaning from 'love' as النجم:3)(وما ينطق عن mentioned in the following verse: 0 (الهوى).

It is interpreted into "impure evil desire and lusts" (Khan and AlHilli,2007:803) . Sometimes, a translator resorts to redundancy... to add some words for explanation. Hence, it can be said that translating words of love is context determined. Newmark (1942:40) ,however, argues that" a translation can be ,more or less, semantic - more, or less, communicative - even a particular section or sentence can be treated more communicatively or less semantically".

It is worthy to mention that the common meaning of the word is the inclination of the heart, while the English word 'love', especially, in modern English, is highly related with sex. Thus, there is no one - to - one equivalence between Arabic and English words of love except, for example, الثوق مشتاق from (longing) - which means the travel of the heart to the beloved - which is when translated into English, the subjects use (have longing, longing, eager, and craving), and these words are almost near equivalent to the word شوق. In line three, the word الصبابة which means " the tendency towards ignorance and misbehaviour" as mentioned in the Holy Quran is translated into (affection, eagerness, love, and passion - twice repeated). And these words are all different from صبابة (the suffering of love).s

'Affection' could mean love; 'eagerness' is perhaps longing; whereas 'passion' means strong emotion associated with sexual love. Thus, it could be argued that the choice of such equivalents except perhaps for 'passion' is unlucky. Therefore, the more disagreement about the translation of a certain word of love, the more loss of meaning is associated in Translation (Mc Guire,1980 :30). This could be shown from an example, taken from the Holy Quran:

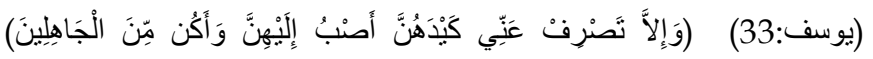
which is interpreted as "I will feel inclined toward them and be one of those who commit sin and deserve blame or those who do deeds of the ignorant". (Khan and Al Hilali, 2007:318). This interpretation gives us the exact image of the word أصب. In another example taken again

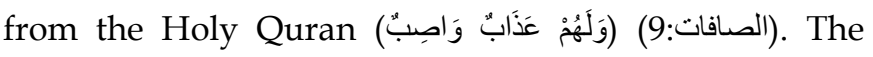
word واصب means constant. Here, it is possible to suggest that when no equivalent is found, a translator could employ paraphrasing for the sake of clarification. In line four, the translators roughly tend to translate الهوى into 'love' (three times) and then into 'affection' and 'acceptance'. Back translation could also show how problematic translating such words are because when one looks at the translation of الهوى الود and, the reader feels that they are perfect synonyms. In fact the first is used carrying a negative sense, as mentioned in the Holy Quran (النازعات:40) while the second one can only be used in a positive sense; it suffices to say that الودود is one of the divine names of Allah - God the Almighty.

Generally speaking, the word 'love' is found to be the 
equivalent by our subjects many times from the first to the sixth lines including the word غرامي. Unlike this pitfall in translating those words, the word لظى, in line seven which is not considered like that, because the word لظى Arabic is used commonly in different contexts with almost similar meanings. This is why the English translations (warmth, flame - translated twice, and burning) seem very close to the Arabic one. This can also be applied to لاعجه and line nine which are respectively translated into (longing - three times, eagerness, and yearning).

Another similar problem is reflected with the words متيم and line eight and line ten respectively, whereby we find not only do the subjects give one translation for many words but also a subject him/herself again gives one translation 'infatuation' for the two Arabic words.

Other subjects gave miscellaneous items as equivalents of (love, intense, passion and emotion) for الجوى and (enslaved, infatuated - twice- and enthralled) for متيم.

Seemingly, the translation of words of love might go with the idea which states that " the lexical meaning of a word or lexical unit may be thought of as a specific value it has in a particular linguistic system, and the 'personality' it acquires through usage within that system". (Baker, 1992:12).

The translation of words of love tends, to a certain extent, to be stylistically determined. It also necessitates that a translator should have a good knowledge of literary translation.

\subsection{Conclusions:}

From the above argument and discussion, we have come up with the following conclusions:

- There is a variety of meanings to the words of love in Arabic; they convey poetic meaningful images, which have no equivalents similar to them in English. And this, in fact, constitutes a difficult task for translators.

- The word 'love' is highly associated with sex in English, especially, modern English, and this shows beyond doubt the way the western society think. Whereas in Arabic, as our research has shown, the word 'love' has a wider range of meanings... it transcends the materialistic limits. And the sexual implication of love comes not as a first thought compared with English.

- The research has advocated and to a large extent Palmer's argument of refuting perfect synonymy despite the fact that the research has tackled only some of them.

- It is worthy to mention that both Arabic and English mentalities express different and/or similar response.

- The research paves the way to more further studies that shed light on such a type, namely human feelings.

\section{References}

1. Ba'lbakki,M.(2010).Al Mawrid (English-Arabic Dictionary). Dar AlElm Lilmalaeen: Beirut.

2. Baker,M.(1992). In Other Words: A Coursebook on Translation. London: Routledge.

3. Catford,J.C.(1965). A Linguistic Theory of Translation. Oxford:Oxford University Press.

4. Ehrlich,E.; Stuart,B.F.; Corton,C.; and Joyce,M.H.(1980). Oxford American Dictionary. New York and Oxford: Oxford University Press.

5. En.wikipedia .org/wiki/love (2017)

6. Fallows,S.(1988). A Complete Dictionary of Synonyms and Antonyms. Fleming H. Revell Company: London.

7. Forums.way2Allah.com

8. https:// sunnah.com

9. Holman,C.H.(1980). A Handbook to Literature. Bob bs-Merrill Educational Publishing(4 $4^{\text {th }} \quad$ ed.): Indianapolis. 
10. Hornby,A.S.(2010). Oxford Advanced Learner's Dictionary. Oxford : Oxford University Press.

11. Khan,M. and T.Al Hilali(2007). Interpretation of the Meanings of The Noble Quran in The English Language. Riyadh: Maktaba Dar-us-Salam.

12. Mc Guire,S.B.(1980). Translation Studies. London: Methuen.

13. Newmark,P.(1982). Approaches to Translation. Oxford: Pergamon Press Ltd.

14. Palmer,F.R.(1980). Semantics. Cambridge: Cambridge University press.

15. Qutub,M.A.(1991). Al Hub Wal Jins Min Manthurin
Islami. Al Juthoor Press: Baghdad.

16. The Glorious Quran. (2010). Riyadh: Majma? AlMalik

17. Fahad bin Abdulaziz for Printing and Distribution.

18. Fahad bin Abdulaziz for Printing and Distribution.

19. www.almaany.com

20. www.islamspirit.com 